\title{
MORFOGENEZA SLEPE DOLINE BRDANSKA DANA
}

Erika Kozamernik, univ. dipl. geog.

Zavrti 33, SI-I 234 Mengeš

e-pošta: erika.sitarjeva@gmail.com

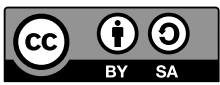

Izvirni znanstveni članek

COBISS 1.01

DOI: 10.4312/dela.45.7.119-133

\section{Izvleček}

Slepa dolina Brdanska dana se nahaja na južnem robu Brkinov, kjer se ti stikajo s kraškim ravnikom Matarskega podolja. Na preučevanem območju se prepletajo značilnosti fluvialnega ter kraškega geomorfnega sistema, kar se kaže v veliki pestrosti reliefnih oblik in procesov. V okviru te raziskave je bila opravljena geomorfološka analiza preučevanega območja. Na podlagi morfografskih, morfometričnih in granulometričnih podatkov smo preučili glavne geomorfološke značilnosti, funkcijo in razvoj te slepe doline.

Ključne besede: kontaktni kras, slepa dolina, udornica, ponikalnica, geomorfologija, Brdanska dana, Brkini, Matarsko podolje, Slovenija

\section{MORPHOGENESIS OF THE BRDANSKA DANA BLIND VALLEY}

\begin{abstract}
Brdanska dana blind valley is situated in the southwestern part of Slovenia where the flysch area of Brkini meets the limestone area of Matarsko podolje. The research area has features of fluvial and karstic geomorphic system, which is shown by a huge variety of geomorphological forms and processes. The morphogenetic interpretation of the geomorphological features, function and the evolution of the blind valley is discussed on the basis of data obtained through detailed geomorphological analysis.
\end{abstract}

Key words: contact karst, blind valley, collapsed doline, sinking stream, geomorphology, Brdanska dana, Brkini, Matarsko podolje, Slovenia 


\section{UVOD}

Skoraj polovico slovenskega ozemlja gradijo zakrasele kamnine. Ker se med seboj razlikujejo po lastnostih in ker se v njih in preko njih pretakajo vode na različne načine, se je na območju Slovenije razvilo mnogo različnih vrst krasa. Eden najkompleksnejših tipov krasa je prav gotovo ponorni kontaktni kras (Gams, 2003; Stepišnik, 2011b). Delež območij, kjer se kontaktni kras pojavlja, je v primerjavi s celotnim obsegom krasa relativno majhen, kljub temu pa je izrednega pomena za razumevanje nastanka in delovanja krasa (Mihevc, 2001). Razvit je na aktivnem hidrološkem stiku zakraselih in nezakraselih kamnin, pri čemer vode $\mathrm{z}$ nekraškega površja tečejo na zakrasele kamnine in nato poniknejo (Mihevc, 1991a).

Najbolj značilen primer ponornega kontaktnega krasa v Sloveniji je Matarsko oziroma Podgrajsko podolje, ki obsega kraški ravnik med Slavniškim pogorjem in Brkini (Stepišnik in sod., 2007a). Z Brkinov, ki jih gradi fliš eocenske starosti (Šikić, Pleničar, 1967), priteka na kras 17 manjših potokov, ki so si v rob ravnika Matarskega podolja, katerega gradijo apnenci in dolomiti kredne ter paleocenske starosti (Šikić, Pleničar, 1967), vrezali različno globoke slepe doline (Mihevc, 1991a; Gams, 2003), ponorne zatrepe (Mihevc, 1991a; 1991b) ali pa celo nasuli vršaje (Stepišnik in sod., 2007a; 2007b; Stepišnik, 2009; 2010a; 2011a).

Kontaktni kras najpogosteje definiramo kot stik med nekarbonatnimi in karbonatnimi kamninami. V ožjem pomenu besede torej pomeni oblike, ki se izoblikujejo na stiku med zakraselimi in nezakraselimi kamninami. V širšem pomenu besede je kontaktni kras tudi kras na stiku dveh vrst zakraselih kamnin, ki se med seboj ločita po kemični sestavi, poroznosti, gostoti razpok in drugih značilnostih (Sauro, 2001; Gostinčar, 2011; Gostinčar, Stepišnik, 2012).

Primer kontaktnega krasa na stiku dveh vrst zakraselih kamnin je kontaktni kras, ki se je razvil na stiku dolomita in apnenca. Dolomit namreč zaradi kemičnih in mehanskih lastnosti prepereva drugače kot apnenec. Na njem se zato lahko pojavlja t.i. fluviokraško preoblikovanje, na stiku z apnenci pa se lahko oblikuje tudi svojevrsten tip kontaktnega krasa (Gostinčar, 2011).

Preučevano območje obsega slepo dolino Brdanska dana s pripadajočima reliktnima slepima dolinama in njenim hidrološkim zaledjem. Nahaja se na skrajnem jugovzhodnem delu litološkega stika med karbonatnimi kamninami Matarskega podolja in fliši Brkinov, tik ob slovensko-hrvaški meji in 1,5 km vzhodno od naselja Starod. Brdanska dana je tipična slepa dolina in je največja v nizu slepih dolin na južnem vznožju Brkinov.

Namen preučevanja je bila geomorfološka analiza slepe doline in njenega hidrološkega zaledja ter morfogenetska interpretacija slepe doline. Cilji raziskave so bili izdelati geomorfološko analizo navedene slepe doline, v okviru katere smo opravili morfografsko, morfometrično in morfostrukturno analizo. Končni cilj je bil na osnovi pridobljenih podatkov podati morfogenetsko interpretacijo slepe doline. 


\section{GEOLOŠKE IN GEOMORFOLOŠKE ZNAČILNOSTI PREUČEVANEGA OBMOČJA}

Brkini so več kot 10 km široko flišno hribovje, ki se skupaj z Jelšanskimi brdi razteza na razdalji $25 \mathrm{~km}$. Na severu jih omejuje dolina reke Reke, na jugu kraški ravnik Matarskega podolja, ki se proti jugovzhodu nadaljuje v Brgudsko podolje (Mihevc, 2001). Najnižje se Brkini spustijo prav na preučevanem območju. Naselje Veliko Brdo, ki stoji v neposredni bližini slepe doline Brdanska dana, se nahaja na nadmorski višini okoli 610 m (GURS, 2015a).

Za Brkine je značilna površinska rečna mreža in posledično razvito fluvialno površje z značilnimi reliefnimi oblikami, kot so slemena, erozijski jarki in doline. Površinska rečna mreža se je oblikovala zaradi neprepustne kamninske zgradbe, saj Brkine gradijo srednjeeocenske flišne kamnine. Izjema so le kvartarni rečni nanosi na dnu slepe doline, ki jih sestavljajo prod, pesek, melj in glina (Šikić, Pleničar, 1967). Na južni strani Brkinov ponikajo številni potoki, ki so na stiku s kraškim ravnikom izoblikovali slepe doline in ponorne zatrepe s korozijsko razširjenim dnom (Mihevc, 1991b; 2001), ki predstavljajo značilne oblike ponornega kontaktnega krasa. Prav na južnem obrobju Brkinov se je na stiku z apnenčastim Matarskim podoljem izoblikoval najdaljši niz slepih dolin v Sloveniji (Mihevc, 1991b). Tipičen primer slepe doline je nedvomno tudi najjužneje ležeča Brdanska dana.

Severni del preučevanega območja gradijo eocenski fliši, kjer se menjavajo plasti peščenjaka, laporovca ter glinavca. Ti sestavljajo tudi celotno hidrografsko zaledje Brdanske dane. Kraški ravnik Matarskega podolja, ki leži v južnem delu preučevanega območja, gradijo apnenci zgornjekredne starosti. Tamkajšnje kraško površje je prekrito s številnimi vrtačami, udornicami in kraškimi jamami, zanj pa je značilna odsotnost površinske rečne mreže (Šikić, Pleničar, 1967).

Brdansko dano je prvi sistematično preučeval Gams (1962), ki jo je imenoval za največjo in najbolj tipično slepo dolino v Brkinih. Po njegovih ugotovitvah je to kilometer dolga, v povprečju $300 \mathrm{~m}$ široka in nekaj več kot $100 \mathrm{~m}$ globoka kotanja. Slepo dolino je definiral kot sestavljeno kraško obliko, ki se pojavlja na prehodu površinske hidrografske mreže v kraško, podzemeljsko (Gams, 1962).

Obravnavano slepo dolino je skupaj z njenim vodozbirnim zaledjem kasneje podrobneje preučeval tudi Mihevc (1991b), ki je natančno opisal njene morfološke in morfometrične značilnosti ter geološko zgradbo. Opredelil je tudi dva različna načina ponikanja vode na območju kontaktnega krasa. Voda tako lahko ponika s filtriranjem skozi naplavino in nato odteka dalje v majhne kanale v živi skali, del vode pa ponika v ponorih, ki so sposobni odvesti celotno količino vode (Mihevc, 1991b).

V okviru naše raziskave smo dosedanja preučevanja nadgradili z ugotovitvami, ki so rezultat podrobne geomorfološke analize slepe doline, v okviru katere je bila prvič opravljena tudi podrobna granulometrična analiza sedimentov. Z njo smo ugotavljali, katere so prevladujoče frakcije, na čemer je temeljila naša kasnejša interpretacija načina sedimentacije teh sedimentov. 
Slika 1: Pregledna karta območja preučevanja.

Figure 1: Location of the studied area.

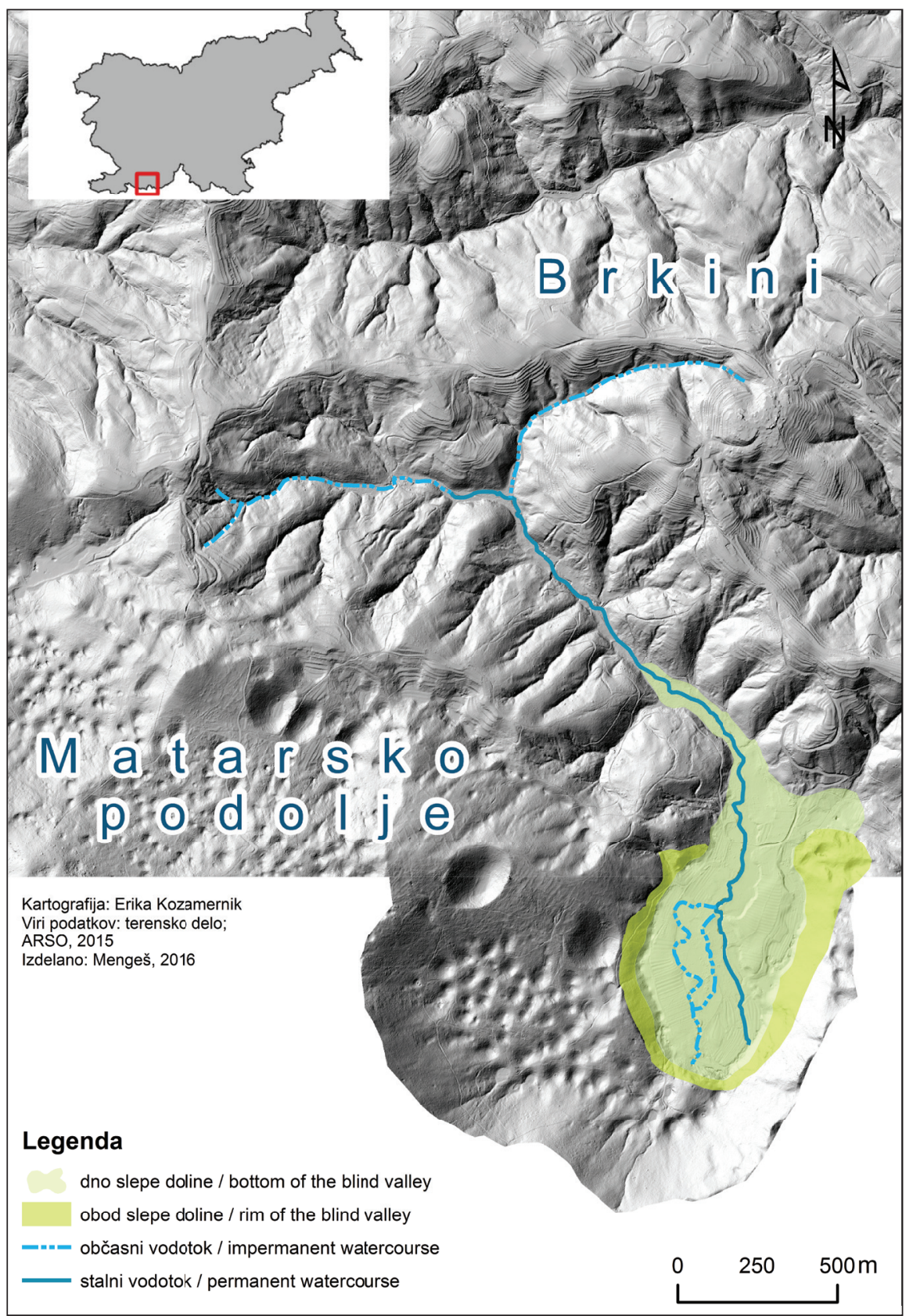




\section{MATERIALI IN METODE}

Za preučevano območje smo pregledali vso relevantno literaturo in kartografsko gradivo. Na celotnem območju preučevanja smo uporabili klasično geomorfološko analitsko metodo (Pavlopoulos, Evelpidou, Vassilopoulos, 2009), ki obsega morfografsko analizo in kartiranje, morfostrukturno analizo ter morfometrično analizo relevantnih oblik.

Osnova za morfografsko kartiranje je bil temeljni topografski načrt v merilu 1 : 5000 (GURS, 2015b). Pri terenski identifikaciji in prostorski umestitvi posameznih oblik smo uporabili tudi obstoječo literaturo (Gams, 1962; Mihevc, 1991b), digitalne ortofoto posnetke, državno topografsko karto v merilu $1: 25.000$ (GURS, 2015a) in lidarske posnetke (ARSO, 2015). Geomorfološke znake in simbole smo povzeli in delno prilagodili po literaturi (Gams, 1968; Demek, 1972; Natek, 1993).

V okviru morfometrične analize površja smo ugotavljali stopnjo razčlenjenosti površja na območju obeh reliktnih slepih dolin, ki je temeljila na gostoti vrtač v posamezni reliktni slepi dolini. Gostoto vrtač smo določili s štetjem vrtač na lidarskih posnetkih. Opravili smo tudi granulometrično analizo sedimentov po klasični pipetni metodi (Vovk Korže, Lovrenčak, 2001), na podlagi katere smo ugotavljali način sedimentacije naplavin $\mathrm{v}$ dnu slepe doline.

Na koncu smo na podlagi geološke zgradbe in rezultatov morfografske ter morfometrične analize podali morfogenetsko interpretacijo slepe doline ter njenega celotnega hidrološkega zaledja.

\section{GEOMORFOLOŠKA ANALIZA BRDANSKE DANE}

Glede na osnovne hidrološke in geomorfološke značilnosti lahko preučevano območje razdelimo na tri dele: fluvialni del, naplavno dno slepe doline ter reliktni del slepe doline.

Fluvialni del predstavlja hidrološko zaledje slepe doline. Ta del preučevanega območja v celoti leži na flišnih kamninah, kar se kaže v številnih erozijskih jarkih in vmesnih slemenih. Značilno je intenzivno mehansko preperevanje, površinska rečna mreža in prevladujoča erozija. Vode z višje ležečih območij se zbirajo v erozijskih jarkih in nato odtekajo proti najnižjim delom, vse do naplavne ravnice. Imajo izrazito hudourniški značaj, kar se kaže v zrnatosti in obliki transportiranega gradiva ter vršajih ob iztekih nekaterih erozijskih jarkov. Kjer se naplavna ravnica nekoliko razširi, je prisoten stalni vodotok, ki površinsko teče vse do ponikev na skrajnem južnem robu dna slepe doline. Vodotok prenaša majhne do srednje velike prodnike flišnih peščenjakov ter drobno peščeno gradivo. 
Slika 2: Geomorfološka karta slepe doline Brdanska dana.

Figure 2: Geomorphological map of the Brdanska dana blind valley.

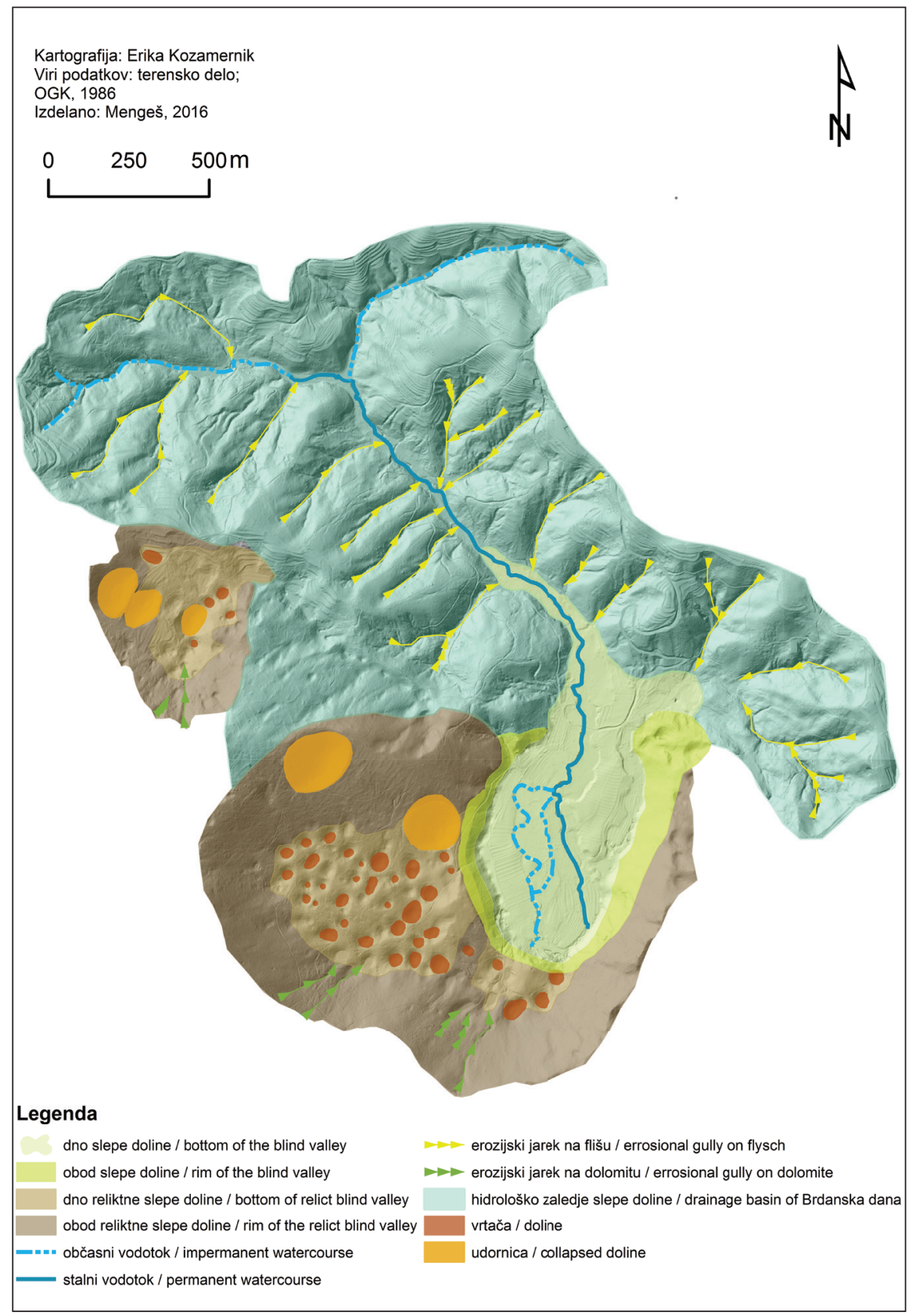


Slika 3: Peščenjakovi prodniki v strugi vodotoka, ki teče po dnu slepe doline (foto: Tadej Sitar).

Figure 3: Sandstone pebbles in the riverbed at the bottom of the blind valley (photo: Tadej Sitar).

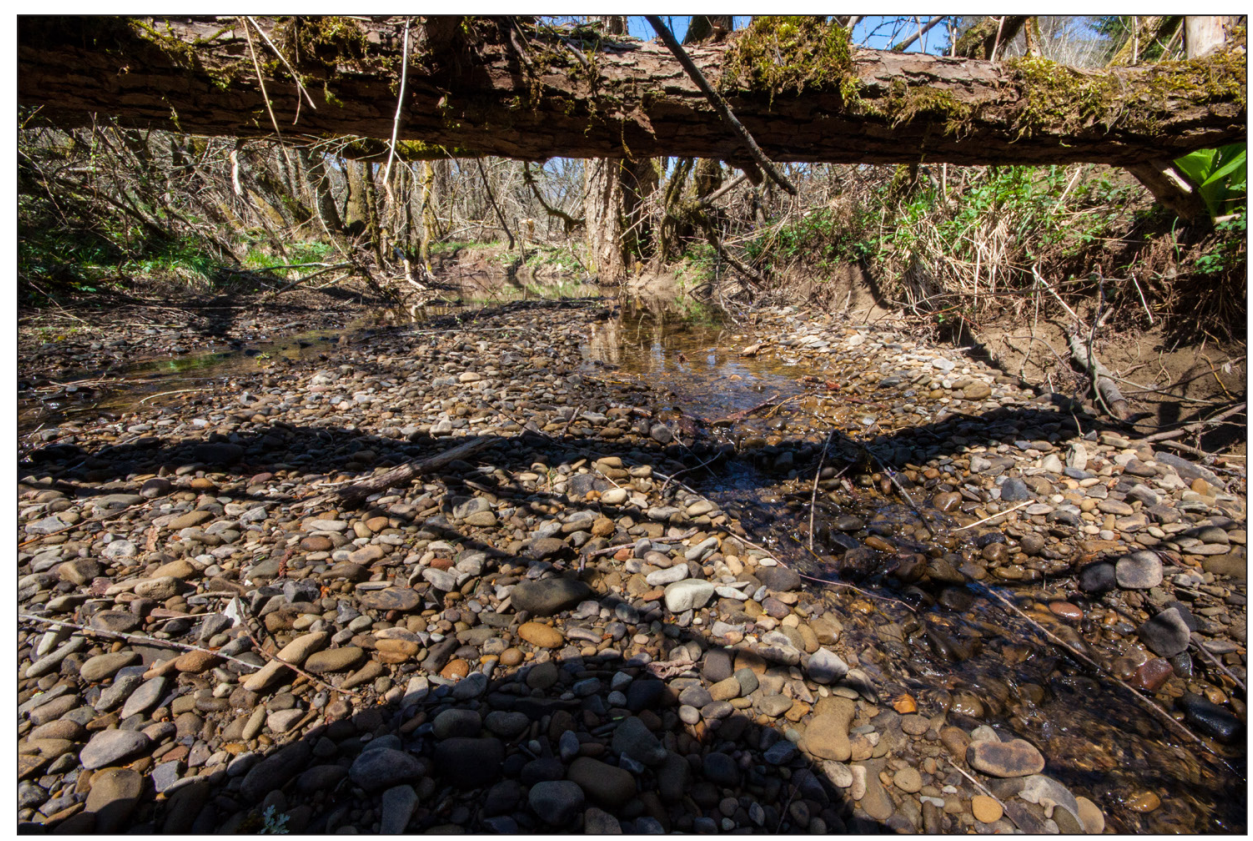

Naplavno dno slepe doline je na severu omejeno z litološkim stikom med flišnimi in karbonatnimi kamninami, medtem ko je na zahodni, južni in vzhodni strani omejeno s strmim apnenčastim obodom. Obsega osrednji in spodnji del doline potoka, ki ponika na njegovem južnem robu, in razširjen del slepe doline ob ponikvah. Naplavna ravnica je razčlenjena v nekaj teras, ki so v zgornjem delu manj izrazite, medtem ko v spodnjem delu, v bližini ponikev, dosegajo relativne višine tudi do $5 \mathrm{~m}$ (slika 5).

Na najvišje ležeči terasi, ki se nahaja v jugozahodnem delu dna slepe doline, ter na današnji aktivni naplavni ravnici v bližini glavnih ponikev smo z ročnim vrtalnikom vzorčili naplavni sediment na različnih globinah. Granulometrijska analiza vzorcev je pokazala, da po deležu frakcij prevladujeta peščena in meljasta ilovica.

Na stiku naplavnega dna in oboda slepe doline se nahajajo številne sufozijske vrtače, ki so razporejene v bližini stika med naplavno ravnico in apnenčasto matično podlago. Najdemo jih tako na vzhodnem kot tudi zahodnem robu naplavnega dna. Na skrajnem južnem robu jih zamenjajo številne manjše ponikve v naplavini, ki so nastale neposredno v strugi vodotoka. 
Slika 4: Melišča na vzhodnih pobočjih s sufozijskimi vrtačami v vznožju (foto: Tadej Sitar). Figure 4: Screes on the western slopes with suffosion dolines at the foot (photo: Tadej Sitar).

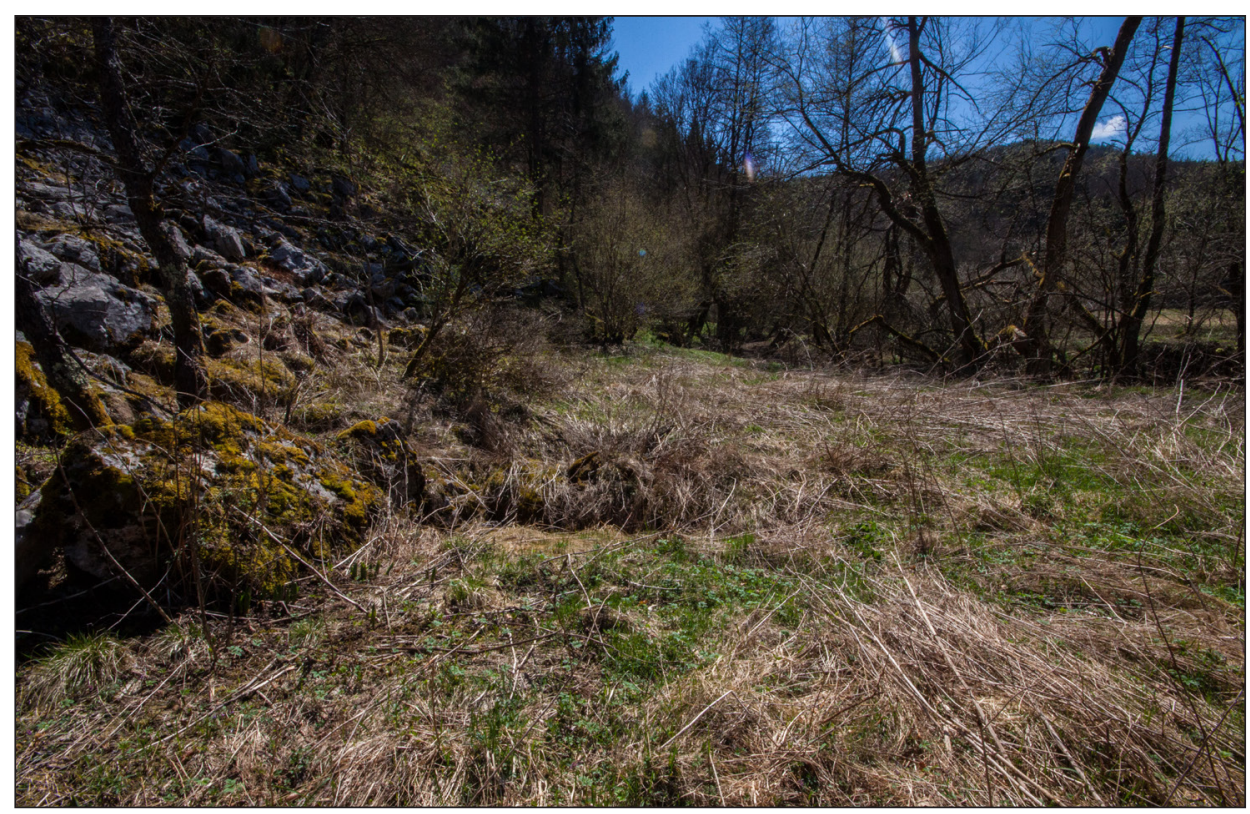

Naplavno dno slepe doline s treh strani obdajajo pobočja, ki so v različnih razvojnih fazah. Na zahodni strani prevladujejo uravnotežena pobočja, na katerih sta denudacija in korozija usklajeni (Stepišnik, 2010b). Povsem drugačna so aktivna vzhodna in južna pobočja. Na njih so vidni sledovi mehanskega pobočnega premeščanja mase, ki je posledica denudacije, katera je v tem primeru intenzivnejša od kemičnega preperevanja (Stepišnik, 2010b). Na vzhodnih pobočjih so tik nad sufozijskimi vrtačami manjša melišča, sestavljena iz velikih do srednje velikih skalnih blokov, na južnih pobočjih pa prevladujejo živoskalne stene. Najvišja stena meri v višino do $10 \mathrm{~m}$ in se nahaja tik nad ponikvami na skrajnem južnem robu naplavnega dna slepe doline.

Nad aktivno slepo dolino se nahajajo tri reliktne slepe doline (na sliki 2 označene s številkami od 1 do 3), ki jih je identificiral že Mihevc (1991b). Najjužnejša in hkrati najnižje ležeča je tudi največja med njimi (št. 1). Zahodno od nje leži nekoliko višja (št. 2), severozahodno od nje pa še tretja, najvišje ležeča reliktna slepa dolina (št. 3). Dna vseh treh reliktnih slepih dolin so razčlenjena z vrtačami. Dno najnižje slepe doline (št. 1) prekrivajo ilovnate zaplate in je najmanj razčlenjeno z vrtačami. Obe višje ležeči reliktni slepi dolini sta popolnoma razčlenjeni z vrtačami, ilovnate zaplate se pojavljajo le v dneh vrtač. Obe sta tudi razčlenjeni z udornicami, ki so razporejene v liniji v smeri severozahod-jugovzhod. Dna udornic so prav tako zapolnjena z ilovnatim sedimentom. V obeh južnih, nižje ležečih reliktnih slepih dolinah (št. 1 in 2) so se izoblikovali manjši erozijski jarki. Ob njihovem vznožju so nastali manjši vršaji, ki delno prekrivajo njihova vrtačasta dna. 
Slika 5: Geomorfološka karta dna slepe doline.

Figure 5: Geomorphological map of the bottom of the blind valley.

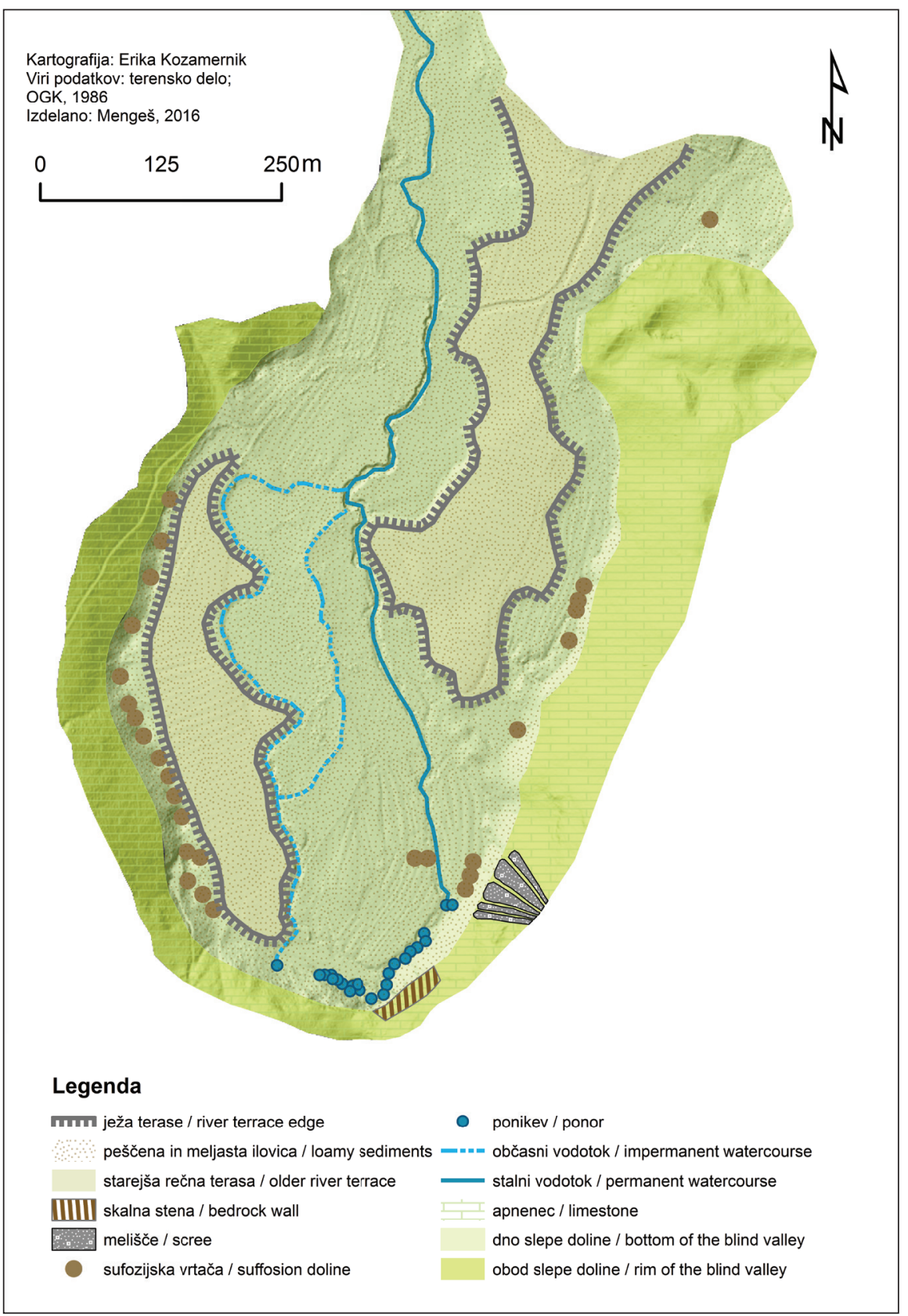




\section{RAZPRAVA}

Slepa dolina Brdanska dana se nahaja na skrajnem jugovzhodnem delu litološkega stika med karbonatnimi kamninami Matarskega podolja in fliši Brkinov, tik ob slovensko-hrvaški meji. Predstavlja tipično slepo dolino in je največja v nizu slepih dolin na južnem vznožju Brkinov.

Potoki, ki pritekajo v slepo dolino Brdanska dana, imajo vodozbirno zaledje v celoti na flišnih kamninah eocenske starosti. Njihov izrazit hudourniški značaj se kaže v strmih pobočjih, globoko zarezanih erozijskih jarkih in zrnatosti naplavin v vršajih ob vznožju erozijskih jarkov.

Terase v akumulacijskem delu slepe doline so razporejene na različnih višinah. Najvišje terase, ki so tudi najstarejše, segajo do $5 \mathrm{~m}$ nad današnjo naplavno ravnico. Ježe starejših teras v grobem sledijo poteku današnjega vodnega toka, iz česar je mogoče sklepati, da se vodne razmere v slepi dolini niso bistveno spreminjale. Na osnovi granulometričnih analiz vzorcev, ki so bili odvzeti na naplavni ravnici, smo ugotovili, da dno slepe doline ni bilo nikoli dlje časa ojezerjeno. Na osnovi zrnatosti sedimentov lahko zaključimo, da so bili delno odloženi neposredno v strugi vodotoka (peščena ilovica), delno kot lebdeči tovor ob občasnih ojezeritvah dna slepe doline (meljasta ilovica).

Številne sufozijske vrtače na stiku naplavnega dna in karbonatnih kamnin potrjujejo hipotezo Mihevca (1991a), da del vode iz slepe doline odteka deloma v ponikve in deloma pronica skozi naplavino in nato odteka $\mathrm{v}$ majhne kanale $\mathrm{v}$ karbonatni matični podlagi. Prav ti vodni tokovi postopoma spirajo naplavino in povzročajo nastanek sufozijskih vrtač.

Na osnovi oblikovanosti pobočij nad naplavno ravnico slepe doline lahko sklepamo, da je najbolj intenzivno sufozijsko spiranje materiala pod vzhodnim in predvsem južnim pobočjem. Južno pobočje, pod katerim danes odteka glavnina vode v številne ponikve, je najbolj strmo, aktivno in z največjo višino sten.

$\mathrm{Na}$ osnovi oblikovanosti zahodnega pobočja lahko sklepamo, da je bil v starejših fazah razvoja odtok voda iz slepe doline najverjetneje prav v tem delu. Tudi skupina udornic, ki se nahaja v liniji prav v zaledju zahodnega pobočja slepe doline, dodatno potrjuje to hipotezo. Hkrati lahko zaključimo, da je v preteklih razvojnih fazah današnjega naplavnega dna slepe doline prihajalo do prestavljanja odtoka, kar se posredno kaže v današnji izoblikovanosti pobočij.

Za razliko od naplavnega dna, kjer prevladujejo fluvialne poteze, so vse tri reliktne slepe doline močno zakrasele. Dna vseh treh razčlenjujejo vrtače in tudi udornice (Stepišnik, 2006; 2011b; 2014; Gabrovšek, Stepišnik, 2011). Najnižjo od reliktnih slepih dolin prekrivajo tudi večje zaplate ilovnatega sedimenta. Na osnovi relativne nadmorske višine, prisotnosti ilovnatih zaplat in najmanjše razčlenjenosti z vrtačami lahko zaključimo, da je najnižje ležeča reliktna slepa dolina tudi najmlajša (št. 1 na sliki 2). Po starosti ji nato sledita srednja (št. 2) in najvišje ležeča, ki je tudi najzahodnejša (št. 3). Na osnovi prostorske razporeditve teh reliktnih slepih dolin lahko zaključimo, da se je prvotno dno Brdanske dane, ki se je ohranilo v najvišji reliktni slepi dolini, postopoma prestavljalo proti jugovzhodu. 


\section{ZAKLJUČEK}

Predmet preučevanja je bila slepa dolina Brdanska dana, ki se nahaja na južni strani Brkinov, neposredno ob slovensko-hrvaški meji. Namen raziskave je bil izdelati geomorfološko analizo navedene slepe doline, v okviru katere smo opravili morfografsko, morfometrično in morfostrukturno analizo, nato pa smo na osnovi ugotovljenega podali še morfogenetsko interpretacijo elementov slepe doline. Na podlagi pregledane obstoječe literature ter lastnih terenskih ugotovitev smo ugotovili sledeče:

- Glede na hidrološke in geomorfološke značilnosti lahko celotno območje razdelimo na tri dele: fluvialni del na severu, naplavno dno slepe doline ter reliktne slepe doline na južnem in jugozahodnem delu območja.

- Za fluvialni del je značilna močna razčlenjenost površja in intenzivna denudacija ter fluvialna erozija. Ta del predstavlja hidrološko zaledje slepe doline.

- Dno slepe doline je sestavljeno iz današnje naplavne ravnice in starejše rečne terase, ki je ohranjena $v$ dveh delih.

- Na stiku naplavnega dna slepe doline z apnenčastim obodom se nahajajo številne sufozijske vrtače in ponikve, kar nakazuje na mesta intenzivnejšega odtekanja vode iz slepe doline.

- Sedimenti v dnu slepe doline so bili odloženi delno neposredno v strugi vodotoka, delno kot lebdeči tovor ob občasnih ojezeritvah dna.

- Dno slepe doline je obdano s pobočji, ki so v različnih razvojnih fazah. Najbolj intenzivni pobočni procesi (premeščanje materiala) so nad današnjim ponornim delom na jugovzhodnem delu oboda.

- Nad južnim in zahodnim delom dna slepe doline ležijo tri reliktne slepe doline, ki so močno zakrasele. Dna reliktnih slepih dolin so gosto razčlenjena z vrtačami, v bližini litološkega stika (fliš - apnenec) se pojavljajo tudi nizi udornic.

- V pobočjih reliktnih slepih dolin se pojavljajo tudi manjši erozijski jarki, katerih nastanek je najverjetneje vezan na pojav fluviokrasa na strmih dolomitnih pobočjih (Stepišnik, Kosec, 2011).

Rezultati naše podrobne geomorfološke analize dopolnjujejo dosedanje poznavanje obravnavanega območja (Gams, 1962; Mihevc, 1991a; 1991b). Na podlagi teh rezultatov smo torej uspeli delno spremeniti dosedanjo morfogenetsko interpretacijo.

\section{Zahvala}

Najlepše se zahvaljujem dr. Urošu Stepišniku za pomoč pri terenskem delu in nasvete pri pisanju članka. Za pomoč pri terenskem delu se zahvaljujem tudi Tadeju Sitarju, Teji Čeru in Živi Novljan. Prav tako se zahvaljujem Tatjani Sitar za pregled angleškega dela članka. 


\section{Literatura in viri}

ARSO, 2015. Podatki lidarskega snemanja. URL: http://gis.arso.gov.si/evode/profile. aspx?id=atlas_voda_Lidar@Arso (citirano 9.11.2015).

Demek, J., 1972. Manual of detailed geomorphological mapping. Praga, Academia, 344 str.

Gabrovšek, F., Stepišnik, U., 2011. On the formation of collapse dolines: a modelling perspective. Geomorphology, 134,1-2, str. 23-31.DOI: 10.1016/j.geomorph.2011.06.007.

Gams, I., 1962. Slepe doline Slovenije v primerjalni metodi. Zbornik VI. kongresa geografov FLRJ v LR Sloveniji od 27.9. do 5. 10. 1961. Gams, I., Ilešič, S., Savnik, R. (ur.). Ljubljana, Geografsko društvo Slovenije, str. 185-190.

Gams, I., 1968. Geomorfološko kartiranje na primeru Rakitne in Glinic. Geografski vestnik, 40, str. 69-88.

Gams, I., 2003. Kras v Sloveniji v prostoru in času. Ljubljana, Založba ZRC, 516 str.

Gostinčar, P., 2011. Kontaktni kras v Kočevskem Rogu in Kočevski Mali gori. Dela, 35, 1, str. 27-44. URL: DOI: 10.4312/dela.35.2.27-44.

Gostinčar, P., Stepišnik, U., 2012. Geomorfološke značilnosti Kočevskega Roga in Kočevske Male gore s poudarkom na fluviodenudacijskem površju. E-GeograFF, 4. Ljubljana, Univerza v Ljubljani, Filozofska fakulteta, Oddelek za geografijo, 97 str. URL: http://geo.ff.uni-lj.si/sites/default/files/e-geograff_4.pdf (citirano 9. 11. 2015).

GURS (Geodetska uprava Republike Slovenije), 2015a. Državna topografska karta Republike Slovenije 1 : 25.000. 182, Ilirska Bistrica in 197, Starod. 1995. 1. izd. 1 : 25.000. Ljubljana, Ministrstvo za okolje in prostor, Geodetska uprava Republike Slovenije. URL: http://egp.gu.gov.si/egp/ (citirano 10. 10. 2015).

GURS (Geodetska uprava Republike Slovenije), 2015b. Temeljni topografski načrt. D1903, D1904, D2043 in D2044. 1990. 1 : 5.000. Ljubljana, Republiška geodetska uprava. URL: http://egp.gu.gov.si/egp/ (citirano 10. 10. 2015).

Mihevc, A., 1991a. Morfološke značilnosti ponornega kontaktnega krasa v Sloveniji. Geografski vestnik, 63, str. 41-50.

Mihevc, A., 1991b. Morfološke značilnosti ponornega kontaktnega krasa: izbrani primeri s slovenskega krasa. Magistrsko delo. Ljubljana, Univerza v Ljubljani, Filozofska fakulteta, Oddelek za geografijo, 206 str.

Mihevc, A., 2001. Contact karst. 9th international karstological school, Classical Karst. Guide-booklet for the excursions. Postojna, Inštitut za raziskovanje krasa ZRC SAZU, 32 str.

Natek, K., 1993. Geomorfološka karta 1 : 100000 list Celje in analiza reliefa sekcije. Doktorska disertacija. Ljubljana, Filozofska fakulteta, Oddelek za geografijo, 260 str.

Pavlopoulos, K., Evelpidou, N., Vassilopoulos, A., 2009. Mapping geomorphological environments. Berlin, Springer, 236 str.

Sauro, U., 2001. Aspects of contact karst in the Venetian Fore-Alps. Acta carsologica, 30, 2, str. 89-102.

Stepišnik, U., 2006. Ilovnate zapolnitve v udornicah v zaledju izvirov Ljubljanice. Dela, 26, str. 75-89. DOI: 10.4312/dela.26.6.75-89. 
Stepišnik, U., 2009. Active and relict alluvial fans on contact karst of the Vrhpoljska brda hills, Slovenia. Acta geographica Slovenica, 49, 2, str. 245-262. DOI: 10.3986/ AGS49201.

Stepišnik, U., 2010a. Relict alluvial fans of Matarsko podolje and Vrhpoljska brda, Slovenia. Zeitschrift für Geomorphologie, 54, 1, str. 17-29. DOI: 10.1127/0372-8854/2010/0054-0002.

Stepišnik, U., 2010b. Udornice v Sloveniji. E-GeograFF, 1. Oddelek za geografijo Filozofske fakultete Univerze v Ljubljani, 118 str. URL: http://geo.ff.uni-lj.si/sites/default/files/e-geograff_1.pdf (citirano 10.10.2015).

Stepišnik, U., 2011a. Reliktni vršaji kontaktnega krasa. E-GeograFF, 3. Oddelek za geografijo Filozofske fakultete Univerze v Ljubljani, 60 str. URL: http://geo.ff.uni-lj. si/sites/default/files/reliktni_vrsaji_kontaktnega_krasa_0.pdf (citirano 10.10.2015).

Stepišnik, U., 2011b. Sedimenti v udornicah na Krasu, Slovenija. Acta geographica Slovenica, 51, št. 2, str. 233-252. DOI: 10.3986/AGS51201.

Stepišnik, U., 2014. Japage: the collapse dolines on Kupres polje, Bosnia and Herzegovina. Dela, 42, str. 5-20. DOI: 10.4312/dela.42.1.5-20.

Stepišnik, U., Černuta, L., Ferk, M., Gostinčar, P., 2007a. Reliktni vršaji kontaktnega krasa severozahodnega dela Matarskega podolja. Dela, 28, str. 29-42. DOI: 10.4312/ dela.28.3.29-42.

Stepišnik, U., Ferk, M., Gostinčar, P., Černuta, L., Peternelj, K., Štembergar, T., Ilič, U., 2007b. Alluvial fans on contact karst: an example from Matarsko podolje, Slovenia. Acta carsologica, 36, 2, str. 209-215. URL: http://carsologica.zrc-sazu.si/downloads/362/ferk4.pdf (citirano 10. 10. 2015).

Stepišnik, U., Kosec, G., 2011. Modelling of slope processes on karst. Acta carsologica, 40, 2, str. 267-273. URL: http://carsologica.zrc-sazu.si/downloads/402/Stepisnik-Kosec.pdf (citirano 10. 10. 2015).

Šikić, D., Pleničar, M., 1967. Osnovna geološka karta SFRJ. Tumač za list Ilirska Bistrica. Beograd, Zvezni geološki zavod, 54 str.

Vovk Korže, A., Lovrenčak, F., 2001. Priročnik za laboratorijske analize prsti v geografiji. Ljubljana, Filozofska fakulteta, Oddelek za geografijo, Pedagoška fakulteta Maribor, 49 str. 


\section{MORPHOGENESIS OF THE BRDANSKA DANA BLIND VALLEY}

\section{Summary}

There is a series of blind valleys representing typical contact karst forms along the flysch-limestone contact in southwestern part of Slovenia. This article discusses Brdanska dana blind valley, which is the most southern blind valley in this series. It is situated right by the Slovenian-Croatian border. This article focuses on the geomorphological analysis of the blind valley through detailed morphographic, morphometric and morphostructural analysis. The morphogenetic interpretation of the blind valley, relict blind valleys and its basin is discussed on the basis of data obtained through detailed geomorphological analysis.

The drainage basins of the streams flowing into the Brdanska dana blind valley consist of impermeable Eocene flysch. These streams' torrential features are reflected in steep slopes, gullies and alluvial fans.

There are river terraces in the accumulation part of the blind valley of which the highest reach even five metres above the present flood plain. The edges of these terraces follow the present riverbed which means that the hydrological conditions have not changed dramatically. On the basis of the granulometric analysis of the sediment at the bottom of the blind valley it was determined that the blind valley has never been flooded for longer periods of time. The sediment was deposited in two different ways: partially directly in the riverbed and partially as a floating material of occasional floods of the flood plain.

Numerous suffosion dolines are positioned along the contact of the blind valley's bottom with the limestone rim. These are locations of the most intensive water seeping into the underground. However, water also drains through the ponors on the southern edge of the valley bottom.

Considering the shape of the slopes around the bottom of the blind valley, it can be deduced that the most intensive slope processes are on the eastern and southern slope. The southern slope is the steepest one, covered with some screes and it also contains the biggest wall, which is approximately 10 metres high. At the foot of the southern slope are situated also the main ponors of the streams which flow at the bottom of the blind valley. The western slope is covered only with smaller screes and is not as active as the southern slope. On the basis of the listed features we can draw a conclusion that in the earlier phases of the blind valley the drainage was right in this part of the blind valley. It can be also concluded that the drainage migrated several times what is reflected in slopes' morphology.

Unlike the active bottom of the blind valley which has features of fluvial and karstic relief, relict blind valleys are much different. They have well-developed karstic relief. Their bottoms are covered with numerous corrosional as well as collapse dolines which are situated close to the contact of flysch and limestone. The bottom of the lowest relict blind valley as far as the altitude is considered, is also covered with loamy sediment. Considering its relative altitude, loamy sediments and the lowest indentation, this relict blind valley proves to be the youngest one. The age of the relict blind valleys is increasing in a 
westward direction. Based on the relict blind valleys arrangement we can draw a conclusion that the original blind valley bottom has migrated in a southeastward direction.

In some parts of the relict blind valleys there are erosional gullies which represent the biggest trouble in morphogenetic interpretation of the area. At the foot of these gullies there are also smaller alluvial fans and corrosional dolines filled with loamy sediments. The explanation of these gullies will be possible when more detailed lithological and structural slope analysis is carried out.

The Brdanska dana blind valley has been geomorphologically mapped and analysed before. The findings of our detailed research not only supplement the existing expertise but also slightly change its morphogenetic interpretation.

(Translated by the author) 